\title{
Manifestation of Enhanced Protein Content during Dehydration Stages of Seed Priming in Tomato
}

\author{
S. Seethalakshmi* and R. Umarani \\ Department of Seed Science and Technology, Tamil Nadu Agricultural University, \\ Coimbatore-3, Tamil Nadu, India \\ *Corresponding author
}

\section{A B S T R A C T}

The present experiment was conducted to study the effect of different durations of

\section{Keywords}

Seed invigouration,

Dehydration and

Reimbibition

Article Info

Accepted:

25 May 2018

Available Online:

10 June 2018 dehydration after imbibition in seed priming. The dehydrated seeds were subjected to different durations of reimbibition and the protein content related to all physiological parameters were observed. The results revealed that, immediately after reimbibition, Protein content was found to be highest in $9 \mathrm{~h}$ and $12 \mathrm{~h}$ dehydrated seed. During the $3 \mathrm{~h}$ of reimbibition, seeds dehydrated for $9 \mathrm{~h}$ and $12 \mathrm{~h}$ recorded the highest level of Protein content ( $11.60 \& 12.02 \%)$, while at the same duration, a lower level of $11.30 \%$ and 10.62 $\%$ in $6 \mathrm{~h}$ and $3 \mathrm{~h}$ dehydrated seed. The seeds which were incompletely dried for $3 \mathrm{~h}$, could record a comparable level of higher Protein content $(11.42 \%)$ only after $12 \mathrm{~h}$ of reimbibition. All other physiological characteristics such as seed germination (\%), seedling length $(\mathrm{cm})$, dry matter production $\left(\mathrm{mg}\right.$ seedling $\left.{ }^{-10}\right)$ and seedling vigour index were also found to be improved as the dehydration progressed from $3 \mathrm{~h}$ to $12 \mathrm{~h}$. The results underscored that completion of dehydration of seeds after seed imbibition part of seed priming is critical in achieving the maximum seed invigouration.

\section{Introduction}

Seed production and distribution of improved varieties of cereals, pulses, oil seeds and vegetables to the farming community is becoming increasingly importantto meet the potential challenge of catering to thefood need of 1.4 billion people of our country by 2025 . Vegetables constitute a major part in Indian agriculture in terms of providing food and nutritional security and also it is important sources of minerals, vitamins and other nutrients of medicinal and therapeutic value. Solanaceous vegetables like tomato, brinjal and chilli have high demand among other vegetable crops in our state as well as in the country (Soubhagya, 2016). Tomato (Solanum lycopersicum L.) is one of the most important edible and nutritious vegetable crop in the world. It gains more popularity due to its antioxidant property. It is a very good source of vitamin $\mathrm{A}$ and $\mathrm{C}$. In order to meet the population challenge, we are in a trouble to increase the production and productivity of food and vegetable crops by adopting various seed enhancement treatments viz., seed priming to enhance the speed and uniformity of germination. 
Seed priming is a pre-sowing treatment that involves exposure of seeds to low external water potential that limits hydration. This hydration is sufficient to permit pregerminative metabolic events but insufficient to allow radicle protrusion through the seed coat (Heydecker et al., 1975). This technique has become a common seed treatment that canincrease rate, percentage and uniformity of germination or seedling emergence, mainlyunder unfavorable environmental conditions.Seed dehydration after priming (drying-back) is also meant for safe storing of primed seeds without losing the advantages achieved with priming.It is a critical step for maintaining seed quality.

Seed proteins are small hydrophilic proteins some of which are structurally related. These proteins contains from 83 to 153 amino acid residues and may play a role in equipping the seed for survival, maintaining a minimum level of hydration in the dry organism and preventing the denaturation of cytoplasmic components.

In developing seeds, storage proteins are synthesized in abundance and accumulate primarily in the protein storage vacuoles of terminally differentiated cells of embryo and endosperm. These proteins may play a role in equipping the seed for survival, maintaining a minimal level of hydration in the dry organism and preventing the denaturation of cytoplasmic components. They may also play a role during imbibition by controlling water uptake.

Priming-induced vigour enhancement studies are numerous, but those highlighting the biochemical and molecular basis of such changesare scarce. For effective use of biochemical and molecular tools and for optimization of priming technique, the interactive mechanism on cellular and molecular events that takes place during priming and on subsequent germination need to be known. Limited number of investigations into the biochemical changes occurring in primed and subsequently germinated seeds have noted changes of pattern of RNA, protein, enzyme activities and DNA synthesis (Dell and Taranto, 1986).

The purpose of this research is to reveal the Protein changes that occur in the seeds during different stages dehydrationafter imbibition in seed priming.

\section{Materials and Methods}

Tomato variety, ArkaVikas were collected with the initial germination and moisture content of $67 \%$ and $8 \%$. Tomato seed priming involves $48 \mathrm{~h}$ of seed imbibition and subsequent dehydration (hydropriming) (Venkatasubramanium and Umarani, 2007).

In the present experiment, tomato seeds were subjected to four different durations of imbibition, dehydration and reimbibition in order to study respective Protein content and Physiological changes.

\section{Treatments}

\section{Dehydration stage}

Seeds imbibed for $48 \mathrm{~h}$ were dehydrated for four different durations of 3, 6, 9 and $12 \mathrm{~h}$.

Seeds dried for $3 \mathrm{~h}$ were reimbibed for $3,6,9$ and $12 \mathrm{~h}$

Seeds dried for $6 \mathrm{~h}$ were reimbibed for 3, 6, 9 and $12 \mathrm{~h}$

Seeds dried for $9 \mathrm{~h}$ were reimbibed for $3,6,9$ and $12 \mathrm{~h}$

Seeds dried for $12 \mathrm{~h}$ were reimbibed for $3,6,9$ and $12 \mathrm{~h}$ 


\section{Protein content}

The protein content of seeds was estimated by the colorimetric method of Ali-khan and Youngs (1973). Hundred mg of ground meal was taken in $950 \mathrm{ml}$ polyethylene screw cap bottle and $25 \mathrm{ml}$ of $1 \mathrm{~N}$ sodium hydroxide was added. The mixture was taken for 30 minutes at a wrist action shaker to disperse the protein. Then $10 \mathrm{ml}$ of the suspension was poured into a graduated test tube and used as a blank to compensate for the differences in the amount of natural pigments extracted and to the remaining suspension in the bottle, $0.25 \mathrm{ml}$ of 10 per cent copper sulphate solution was added and the bottle was reshaken for an additional duration of five minutes to develop the colour complex. The sample solution was then poured into a separate test tube and left overnight along with its blank to allow the dispersed material to settle down. After centrifugation for 10 minutes the optical density (OD) of the clear supernatant solution was measured in a ELICO UV-VIS spectrophotometer (model SL-159) using red filter $(620 \mathrm{~nm})$ with suitable blank. From the mean OD value the protein percentage for each treatment was calculated, using the following formula:

Protein percentage $=3.78+(61.6 \times$ OD value $)$

\section{Physiological parameters}

The seeds primed as described above were subjected to germination test with four replicate of 100 seeds in paper towels. The test conditions were $25 \pm 2^{\circ} \mathrm{C}$ and $95 \pm 5$ per cent $\mathrm{RH}$, illuminated with fluorescent light. The number of normal seedlings were counted after 14 days and expressed as germination percentage (ISTA, 1999). At the end of fourteenth day of sowing the number of normal seedlings in each replication was counted and the mean percentage germination was calculated as whole number. The length of the normal seedlings were measured and expressed in $\mathrm{cm}$ and measured seedling were dried in a hot air oven maintained at $85^{\circ} \pm 2^{\circ} \mathrm{C}$ for $24 \mathrm{~h}$, then cooled in desiccation and weight was recorded in $\mathrm{mg}^{-10}$ seedling.The vigour index was computed by multiplying percentage germination and seedling length (cm) and expressed as a whole number (Abdul-baki and Anderson, 1973). Data were analysed using an analysis of variance (ANOVA) as a factorial combination of treatments. Means were separated on the basis of least significant difference (LSD) only if $\mathrm{F}$ test of ANOVA for treatments was significant at the 0.05 or 0.01 probability level. Percentage data were arcsine transformed before analysis. Percentage data were arcsine transformed before analysis.

\section{Results and Discussion}

Seed priming involves the controlled hydration of seeds followed by drying to original moisture content. In the seed germination test conducted to compare the seed germination and vigour performance of primed seeds, it was found that significant improvement was obtained with seed priming (Venkatasubramaniam and Umarani, 2004). The primed seeds recorded 19 per cent improvement in seed germination per cent. In the seedling growth also primed seeds were clearly superior to the 'control' seeds. The root length $(\mathrm{cm})$ and shoot length $(\mathrm{cm})$ recorded in primed seeds was 76 and 11 per cent increase over control. Eventually, the dry matter production $\left(\mathrm{mg}^{-10}\right.$ seedlings) and seedling vigour index registered 75 and 79 per cent increase in primed seeds over control (Fig. 1).

In the present study, in order to prime the seeds, tomato seeds were imbibed in water for $48 \mathrm{~h}$ (Venkatasubramaniam and Umarani, 2004) and later subjected to four stages of dehydration for $3 \mathrm{~h}, 6 \mathrm{~h}, 9 \mathrm{~h}$ and $12 \mathrm{~h}$. 
Table.1 Effect of progressive dehydration of imbibed seeds on Protein content $(\%)$ of tomato seeds

\begin{tabular}{|l|c|c|c|c|}
\hline Treatments & $\begin{array}{c}\text { 3h } \\
\text { reimbibition }\end{array}$ & $\begin{array}{c}\text { 6h } \\
\text { reimbibition }\end{array}$ & $\begin{array}{c}\text { 9h } \\
\text { reimbibition }\end{array}$ & $\begin{array}{c}\text { 12h D } \\
\text { reimbibition }\end{array}$ \\
\hline Control - 10.06 & & & & \\
\hline 3h D & 10.62 & 11.23 & 11.36 & 11.42 \\
\hline 6h D & 11.30 & 12.03 & 12.16 & 12.16 \\
\hline 9h D & 11.60 & 12.40 & 12.77 & 12.87 \\
\hline 12h D & 12.02 & 13.82 & 14.21 & 14.65 \\
\hline
\end{tabular}

Table.2 Effect of progressive dehydration of imbibed seeds on germination Characteristics of tomato

\begin{tabular}{|c|c|c|c|c|}
\hline $\begin{array}{c}\text { Duration of } \\
\text { Dehydration }\end{array}$ & $\begin{array}{c}\text { Germination } \\
(\%)\end{array}$ & $\begin{array}{c}\text { Seedling } \\
\text { length }(\mathbf{c m})\end{array}$ & $\begin{array}{c}\text { Dry matter production } \\
\left(\mathbf{m g}^{-10} \text { seedlings }\right)\end{array}$ & $\begin{array}{c}\text { Vigour } \\
\text { index }\end{array}$ \\
\hline $\mathbf{3}$ h & $64(53.13)$ & 17.32 & 18 & 1108 \\
\hline $\mathbf{6}$ h & $66(54.33)$ & 18.05 & 19 & 1191 \\
\hline $\mathbf{9}$ h & $73(58.70)$ & 19.47 & 21 & 1421 \\
\hline $\mathbf{1 2}$ h & $74(59.34)$ & 20.48 & 21 & 1516 \\
\hline SEd & $\mathbf{1 . 2 8 2 4}$ & $\mathbf{0 . 3 1 9 7}$ & $\mathbf{0 . 0 0 0 3}$ & $\mathbf{2 7 . 4 0 7 6}$ \\
\hline CD (0.05\%) & $\mathbf{2 . 8 5 7 3}$ & $\mathbf{0 . 7 1 2 4}$ & $\mathbf{0 . 0 0 0 7}$ & $\mathbf{6 1 . 0 7 2 8}$ \\
\hline CV & $\mathbf{2 . 3 2}$ & $\mathbf{2 . 2 2}$ & $\mathbf{1 . 9 8}$ & $\mathbf{2 . 8 0}$ \\
\hline
\end{tabular}

Fig.1 A comparison of seed germination and seedling growth potential of primed and Unprimed seeds of tomato

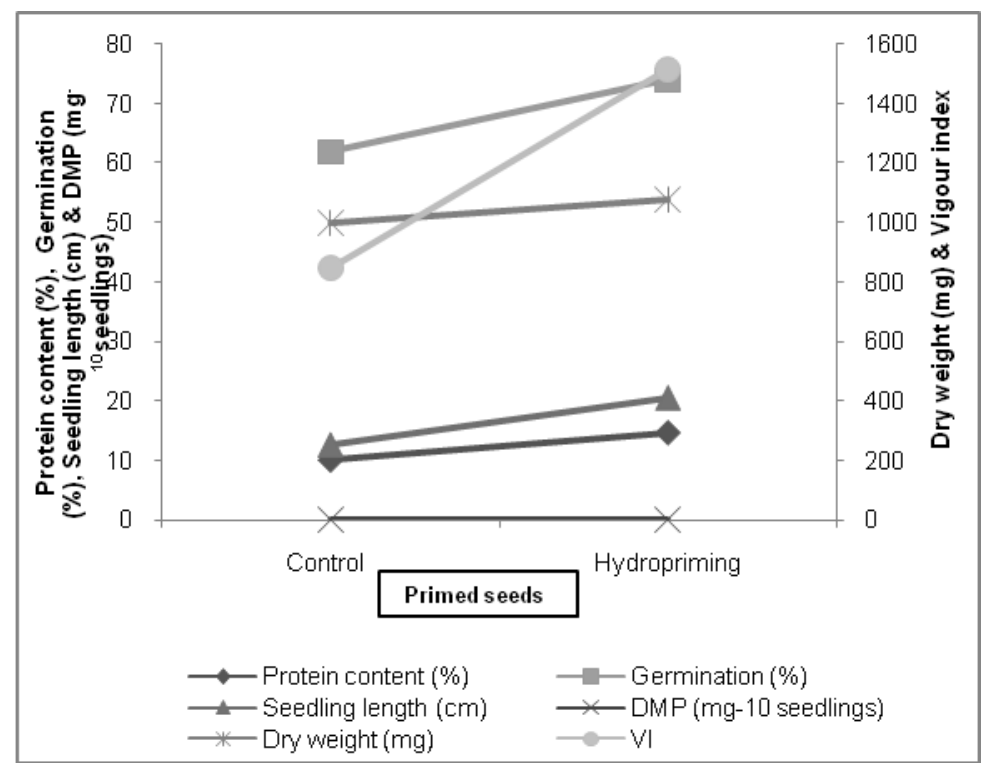


Fig.2 Effect of progressive dehydration of imbibed seeds on Protein content (\%) of tomato seeds

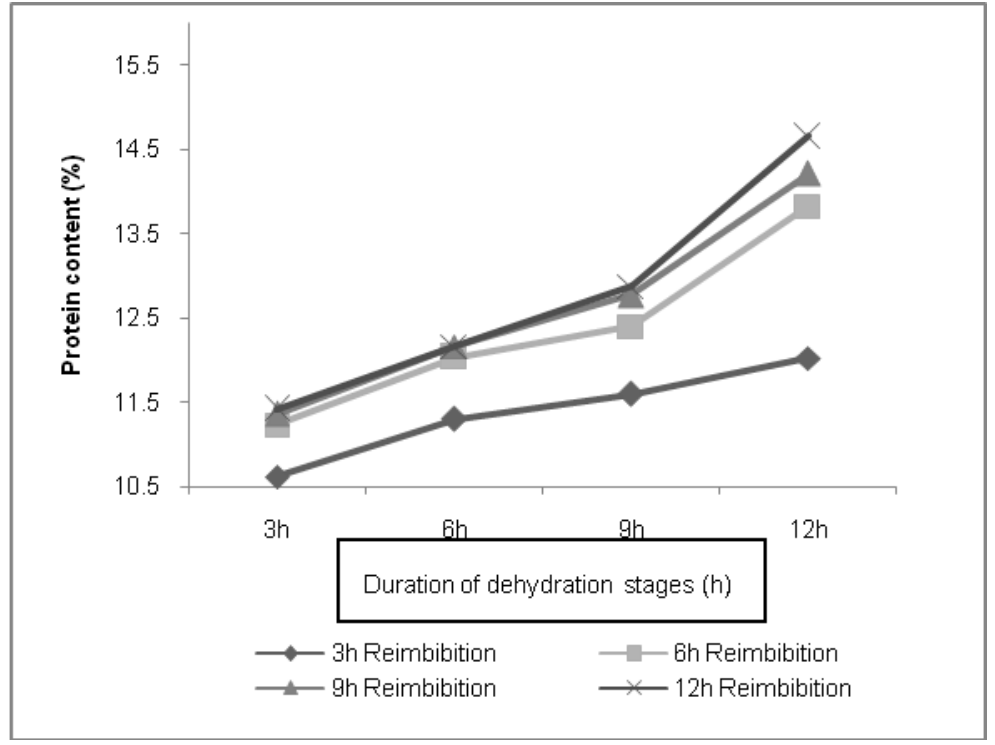

Fig.3 Effect of progressive dehydration of imbibed seeds on germination Characteristics of tomato

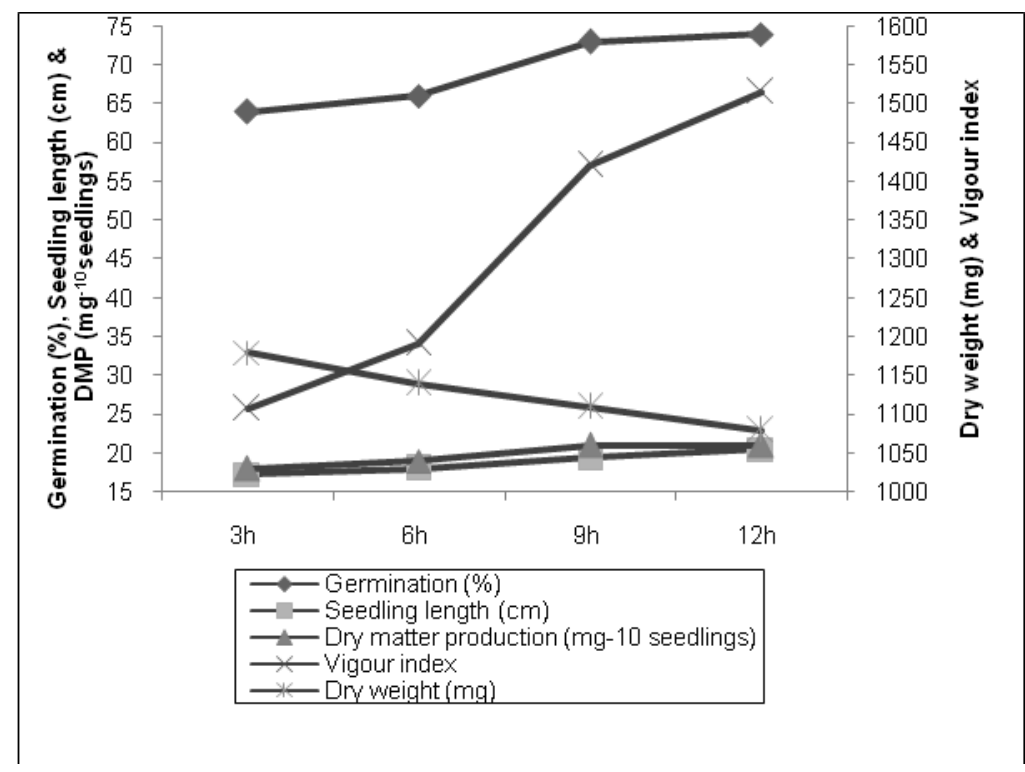

In order to study the activation of Protein synthesis, after each stages of dehydration $i e$., $3 \mathrm{~h}, 6 \mathrm{~h}, 9 \mathrm{~h}$ and $12 \mathrm{~h}$, seeds were subjected to four stages of reimbibitionviz., $3 \mathrm{~h}, 6 \mathrm{~h}, 9 \mathrm{~h}$ and $12 \mathrm{~h}$. The content of Protein synthesised in each stage of dehydration was estimated and the data is presented in Table 1 and Figure 2. The results revealed that, immediately after reimbibition, Protein content was found to be highest in $9 \mathrm{~h}$ and 12 $\mathrm{h}$ dehydrated seed. During the $3 \mathrm{~h}$ of reimbibition, seeds dehydrated for $9 \mathrm{~h}$ and 12 $\mathrm{h}$ recorded the highest level of Protein content (11.60 \& $12.02 \%)$, while at the same duration, a lower level of $11.30 \%$ and 10.62 $\%$ in $6 \mathrm{~h}$ and $3 \mathrm{~h}$ dehydrated seed. The seeds 
which were incompletely dried for $3 \mathrm{~h}$, could record a comparable level of higher Protein content $(11.42 \%)$ only after $12 \mathrm{~h}$ of reimbibition.

The data puts forth that dehydration process played a critical role in 'invigouration' of seeds, because with respect to Protein content it was observed that 'as the level of dehydration advanced, there was a corresponding increase in Protein content of the seeds'. It has been assumed that the onset of germination is associated with a rapid resumption of RNA and protein biosynthesis (Osborne, 1983).Thus, it appears that there is a loss of conserved mRNA during the first few hours of germination and an increase in new messages, with protein synthesis becoming increasingly dependent on the latter with time of germination. Proteins essential for the successful completion of the germination process per se, culminating in the elongation of the radicle. Protein synthesis does not occur in the dry seed of course, but commences when cells are sufficiently hydrated to allow cytoplasmic (eukaryotic 80 S) ribosomes to associate with messenger RNA (mRNA).

In order to study the effect of synthesis of protein during invigoration of seeds, the germination characteristics were also studied. The results revealed that synthesis of protein during priming will stimulate the germination and growth potential of the seeds. The seed germination was minimum in $3 \mathrm{~h}$ dehydrated seed (64 per cent), whereas it increased steadily to record 66 per cent $(6 \mathrm{~h}$ dehydration), 73 per cent ( $9 \mathrm{~h}$ dehydration) and reached 74 per cent with $12 \mathrm{~h}$ of dehydration. The seedling growth was also found to correspondingly increase from 17.32 $\mathrm{cm}$ ( $3 \mathrm{~h}$ of dehydration) to $20.48 \mathrm{~cm}(12 \mathrm{~h}$ dehydration); while dry matter production increased from $18 \mathrm{mg}^{-10}$ seedlings at $3 \mathrm{~h}$ of dehydration to $21 \mathrm{mg}^{-10}$ seedlings at $12 \mathrm{~h}$ dehydration. The vigour index registered in seeds dehydrated for $3 \mathrm{~h}$ was 1108 , whereas it increased steadily to 1191 ( $6 \mathrm{~h}$ dehydration), 1421 (9 h dehydration) and $1516(12 \mathrm{~h}$ dehydration) (Table. $2 \&$ Fig. 3). The enzymatic activity which is provoked by the seed is directed towards there pair of damages which have accumulated during maturation, storage and imbibition (Osborne, 1983). Gradually, the syntheses of proteins, RNAs and DNA, and nuclear replication or cell division in some seed species occur before visible germination (Bino et al., 1993). All these metabolic activities in combination with water uptake by the seeds, result in the growth of embryo. Visible germination occurs when the potential of the embryo growth exceeds the restraint as imposed by the surrounding tissues. It is widely accepted that protein synthesis is a pre-requisite for radicle emergence. The seeds of high plants accumulate large amounts of storage proteins during seed development and seed maturation, which are mobilized to provide building blocks and energy for seed germination and early seedling growth upon seed germination (Bewley and Black, 1994). There is some contention as to whether or not this protein synthesis is dependent upon prior RNA synthesis, but there can be no doubt that DNA synthesis only occurs after germination as an integral part of growth of the axes.

\section{References}

Abdul-Baki, A.A., and Anderson, J.D. 1973. Vigour determination of soybean seeds by multiple criteria, Crop Sci., 13: 630633.

Ali-khan, S.T., and Youngs, C.G.1973. Variation in protein content of field peas. Can. J. Pl. Sci., 53: 37-41.

Bewley, J. D., and Black, M. 1994. Seeds: Physiology of Development and Germination, Ed2. Plenum Press, New York. 
Bino, R. J., Lanteri, S., Verhoeven, H.A., and Kraak, H.L. 1993. Flow cytometric determination of nuclear replication stages in seed tissues. Annals of Botany. 72:181-187

Dell'Aquila, A., and Taranto, G. 1986. Cell division and DNA synthesis during osmopriming treatment and following germination in aged wheat embryos.Seed Sci. Technol. 14: 333342.

Heydecker, W., Higgins, J., and Turner, Y.J. 1975. Invigoration of seeds. Seed Sci. Technol., 3 (3/4): 881-888.

ISTA.1999. International Rules for Seed Testing. Seed Sci. and Technol., Supplement Rules, 27: 25-30.

Osborne, D.J. 1983. Biochemical control systems operating in the early hours of germination. Canadian Journal of Botany. 61:3568-3577

Soubhagyabehera. 2016. A study on the effect of hormonal priming (GA3) on seed quality parameters of solanaceous vegetables. Int. J. of Agrl. Sci. and Res. 6(3): $337-348$

Venkatasubramaniam, R., and Umarani, R. 2004. Promising priming techniques for high quality vegetable seeds. Asian seed and planting material. 11(6): 11-12.

Venketasubramaniam, A., and Umarani, R. 2007. Evaluation of seed priming methods to improve seed performance of tomato (Lycoperison esculentum), eggplant (Solanum melongena) and chilli (Capsicum annum). Seed Sci\& Tech. 35-2 (In Press.).

\section{How to cite this article:}

Seethalakshmi S. and Umarani R. 2018. Manifestation of Enhanced Protein Content during Dehydration Stages of Seed Priming in Tomato. Int.J.Curr.Microbiol.App.Sci. 7(06): 37613767. doi: https://doi.org/10.20546/ijcmas.2018.706.440 